\title{
THE EFFECT OF SEAWEED POWDER (Eucheuma cottonii) ADDITION IN CATFISH SAUSAGE
}

\author{
Lisa Amanda Yakhin 1)*, Kristalia Mulya Wijaya1), Joko Santoso2)
}

1) Dept. of Food Technology, Faculty of Science and Technology, Universitas Pelita Harapan *e-mail : lisa.yakhin@uph.edu, +62-21-5460901

2) Dept. of Aquatic Products Technology, Faculty of Fisheries and Marine Sciences, Bogor Agricultural University

\begin{abstract}
Sangkuriang catfish (Clarias gariepinus) is one of freshwater fish which gives low gelling capacity due to its high content of sarcoplasmic protein and lipid contents. Catfish surimi was made into fish sausage with tapioca starch as filler and seaweed powder as gelling agent. Seaweed Eucheuma cottonii have ability to increase gelling properties because of its hydrocolloid content, carrageenan. In this research, different concentrations of E. cottonii seaweed powder were added to fish sausage. E. cottonii powder improved gel strength $(1816.69 \mathrm{g.cm})$, WHC $(88.67 \%)$ of fish sausage without giving any effect to the sensory properties of fish sausage (aroma, flavor, off-flavor, color). The best concentration of E. cottonii powder adding was $0.50 \%$. Fish sausage added with seaweed powder $(0.50 \%)$ had comparable WHC, gel properties (gel strength, biting and folding test) and sensory properties with commercial fish sausage marketed in Indonesia. Furthermore, fish sausages added by either seaweed powder had higher whiteness degree, whiter color, and higher dietary fiber content compare to commercial fish sausage.
\end{abstract}

Keywords : catfish, Eucheuma cottonii, fish sausage, seaweed powder

\section{INTRODUCTION}

According to Sen (2005), fish meat is usually processed into semi-processed product, surimi, as well as processed products like nugget, fishball and sausage. Sangkuriang catfish (Clarias gariepinus) is a fatty fish and has high sarcoplasmic protein content. Fat and high sarcoplasmic protein content impairs gel forming ability (Sun and Holley 2010). Catfish also possesses unpleasant soil odor. Undesirable components can be removed by washing; hence washing improves texture, color and aroma of fatty fish (Chaijan et al. 2010; Yada 2004). Some seaweed own the ability of gel forming, one of them is Eucheuma cottonii seaweed which produces kappa-carrageenan (Pietrasik 2003; Ramirez et al. 2011).

In this research, catfish meat was utilized into surimi with washing treatment and further processed into fish sausage. Good fish sausage requires springy texture and high water holding capacity (WHC) (Santoso et al., 2008). The E. cottonii powder was also applied as gelling agent in order to improve its gel properties.

ISSN 2413-0877 @ 2015 The Authors.

Published by KnowledgeE Publishing Services. This is an open access article under the CC BY-NC-ND license

(http://creativecommons.org/licenses/by-nc-nd/4.0)

Selection and peer-review under responsibility of the 1st ISAPPROSH 2013

DOI : http://dx.doi.org/10.18502/kls.v1i0.76 


\section{MATERIAL AND METHODS}

Sangkuriang catfish was obtained from local market at Serpong, Tangerang, Indonesia, while E. cottonii was obtained from Banten Province and Lombok Island, Indonesia, respectively. This research was divided into two parts. Preliminary research consisted of seaweed powder making and its physico-chemical characterization; and making Sangkuriang catfish surimi. Minced catfish was washed one time with cold water for 10 minutes with water to fish ratio was 4:1. The surimi making process was done according to Santoso ef al. (2008) with modification with salt addition to improve the gel properties. Sodium bicarbonate $(0.5 \%)$ and sodium chloride $(0.3 \%)$ was added during washing to improve gel strength.

The acid insoluble ash content was determined by using the removing the acid soluble ash in hydrochloric acid 10\% (Sudarmadji ef al. 1996). Gel strength of seaweed powder was done by TA.XT Texture Analyzer (Syamsuar 2006) while analysis of sulfate content of seaweed powder was done according to the method of FMC Corp (1977) in Syamsuar (2006). Analysis of WHC was done by using centrifugation method (Gunenc 2007).

In main research the best concentration of seaweed powder in fish sausage was determined. Concentration used was $0.25 \%, 0.50 \%, 0.75 \%$ and $1 \%$ from total formulation. Fish sausages made from the chosen concentrations were compared with commercial fish sausage. The fish sausage was made from $100 \mathrm{~g}$ of catfish surimi, $5 \mathrm{~g}$ tapioca flour, $10 \mathrm{~g}$ of ice, $10 \mathrm{~g}$ of corn oil, $5 \mathrm{~g}$ of skim milk powder, $0.3 \mathrm{~g}$ of salt, $0.3 \mathrm{~g}$ of pepper, $0.3 \mathrm{~g}$ of sugar, $0.3 \mathrm{~g}$ of garlic powder, $0.3 \mathrm{~g}$ of STPP, $0.1 \mathrm{~g}$ of sodium glutamate, and seaweed powder.

Parameters analyzed for fish sausage were $\mathrm{WHC}(\%)$; gel strength $(\mathrm{g} . \mathrm{cm})$; degree of whiteness (\%); biting and folding test; organoleptic properties; water, ash, fat, protein, carbohydrate and fiber content (\%). Proximate analyzes were done according to AOAC Method as well as dietary fiber which was analyzed by using enzymatic method (AOAC 2005). Gel strength, biting and folding test were done towards fish sausage according to the method of Amiza and Ain (2012), Cardoso et al. (2008) and Nippon Suisan Kaisha Ltd (1980), respectively.

All treatments in preliminary and main research were done in three replications with duplo analysis for each sample.

\section{RESULTS AND DISCUSSION}

\section{E. cottonii seaweed powder}

The characteristic of seaweed powder made E. cottonii can be seen in Table 1. The gel strength of $E$. cottonii powder was lower than the gel strength of carrageenan extracted from E. cottonii which was 1534 g.cm (Yakhin 2008). 
Table 1. Physico-chemical characteristic of seaweed powder

\begin{tabular}{lr}
\hline Characteristic & E. cottonii powder \\
\hline Yield $(\%)$ & $36.70 \pm 1.41$ \\
Degree of whiteness $(\%)$ & $62.43 \pm 0.06$ \\
Gel strength $(\mathrm{g} . \mathrm{cm})$ & $1106.83 \pm 9.31$ \\
Melting point $\left({ }^{\circ} \mathrm{C}\right)$ & $71.75 \pm 1.06$ \\
Gelling point $\left({ }^{\circ} \mathrm{C}\right)$ & $35.75 \pm 0.35$ \\
Moisture content $(\%)$ & $10.59 \pm 0.19$ \\
Ash content $(\%)$ & $15.30 \pm 0.09$ \\
Acid insoluble ash content $(\%)$ & $1.40 \pm 0.19$ \\
Sulfate content $(\%)$ & $18.04 \pm 0.35$ \\
\hline
\end{tabular}

Acid insoluble ash is the insoluble chlorine salt and heavy metals salt such as silica and lead. The maximum content of it in carrageenan is $1 \%$ (Prakashan 2008). The high content of acid insoluble ash in this research was due to no purification process done. Higher sulfate content will give lower gel strength (Soriano 2001).

\section{Addition of E. cottonii powder as gelling agent in catfish sausage}

E. cottonii powder significantly improved the gel of catfish sausage. Gel strength of fish sausage was increased by the addition of E. cottonii powder (Table 3) due to kappacarrageenan which had showed its ability to improve gel strength in fish product (Ramirez ef al. 20111 .

E. cottonii also improved the folding test result and WHC. Li and Jiang (2004) stated that E. cottonii powder increased moisture in gel matrix and formed stronger gel. WHC was increased with the increasing of $E$. cottonii powder concentration.

Table 3. The effect of $E$. cottonii powder addition in catfish sausage

\begin{tabular}{lrrrrr}
\hline \multirow{2}{*}{ Parameter } & \multicolumn{5}{c}{ E. cottonii powder concentration (\%) } \\
\cline { 2 - 6 } & \multicolumn{1}{c}{0.00} & \multicolumn{1}{c}{0.25} & \multicolumn{1}{c}{0.50} & \multicolumn{1}{c}{0.75} & \multicolumn{1}{c}{1.00} \\
\hline Gel strength (g.cm) & $1,616.13^{\mathrm{a}}$ & $1,640.88^{\mathrm{a}}$ & $1,816.69^{\mathrm{b}}$ & $1,870.42^{\mathrm{bc}}$ & $1,965.71^{\mathrm{c}}$ \\
Folding test & $3.45^{\mathrm{a}}$ & $4.11^{\mathrm{ab}}$ & $4.23^{\mathrm{ab}}$ & $4.16^{\mathrm{b}}$ & $4.36^{\mathrm{b}}$ \\
Degree of whiteness (\%) & $65.66^{\mathrm{b}}$ & $65.56^{\mathrm{b}}$ & $64.07^{\mathrm{ab}}$ & $63.25^{\mathrm{a}}$ & $62.87^{\mathrm{a}}$ \\
WHC (\%) & $85.48^{\mathrm{a}}$ & $85.59^{\mathrm{a}}$ & $88.67^{\mathrm{ab}}$ & $88.86^{\mathrm{ab}}$ & $93.78^{\mathrm{b}}$ \\
\hline Note: different superscripts shows significant difference $(p<0.05)$ for each parameter Folding test 1 - 5: gel was
\end{tabular}

broken into fragments with finger pressure - no cracks on folding into quarters

Based on sensory evaluation, E. cottonii did not affect sensory properties (aroma, taste, bitterness, color) of fish sausage (Table 4). Fish has strong and dominant flavor, thus it mimicked the seaweed powder flavor.

Table 4. Scoring test result of catfish sausage added with E. cottonii powder

\begin{tabular}{cccccc}
\hline \multirow{2}{*}{ Parameter } & \multicolumn{5}{c}{ E. cottonii powder concentration (\%) } \\
\cline { 2 - 6 } & 0 & 0.25 & 0.50 & 0.75 & 1.00 \\
\hline Savory aroma & $3.47 \pm 1.04^{\mathrm{a}}$ & $3.27 \pm 0.98^{\mathrm{a}}$ & $3.33 \pm 0.92^{\mathrm{a}}$ & $3.47 \pm 0.86^{\mathrm{a}}$ & $3.20 \pm 1.00^{\mathrm{a}}$ \\
Savory taste & $3.67 \pm 0.99^{\mathrm{a}}$ & $3.77 \pm 1.13^{\mathrm{a}}$ & $3.47 \pm 0.97^{\mathrm{a}}$ & $3.60 \pm 0.81^{\mathrm{a}}$ & $3.67 \pm 0.76^{\mathrm{a}}$ \\
Bitter taste & $1.87 \pm 0.82^{\mathrm{a}}$ & $1.83 \pm 0.74^{\mathrm{a}}$ & $1.67 \pm 0.55^{\mathrm{a}}$ & $1.87 \pm 0.51^{\mathrm{a}}$ & $1.83 \pm 0.59 \mathrm{a}$ \\
Color & $3.70 \pm 0.53^{\mathrm{a}}$ & $3.73 \pm 0.52^{\mathrm{a}}$ & $3.80 \pm 0.48^{\mathrm{a}}$ & $3.73 \pm 0.58^{\mathrm{a}}$ & $3.63 \pm 0.55^{\mathrm{a}}$ \\
\hline
\end{tabular}

Note: different superscripts shows significant difference $(p<0.05)$ for each parameter Scoring test $1-5$ : least strong - very strong; color $1-5$ : very dark - very bright 
Different concentrations of $E$. cottonii powder were tested against commercial fish sausage for gel strength, folding test, degree of whiteness and WHC. Concentration of $0.50 \%$ was not significantly different with commercial fish sausage, thus it was chosen.

\section{Comparison of Commercial Fish Sausage and Catfish Sausage with and without Seaweed Powder}

Further, three types of catfish sausage and one commercial fish sausage were compared. There were control sausage; catfish sausage with $E$. cottonii $0.50 \%$; and commercial fish sausage.

Table 5 showed that the gel strength, folding test result and water holding capacity of catfish sausages added with seaweed powder were improved compared to the control (catfish sausage without addition of seaweed powder), yet it was comparable with commercial fish sausage. Hence, the addition of seaweed powder had improved the poor gel properties owned by catfish to the quality which is approved by the market (commercial fish sausage). However the high degree of whiteness obtained from catfish sausage was assumed to be caused by different processing step done from commercial fish sausage.

Catfish sausage with seaweed powder also had comparable proximate content with commercial fish sausage (Table 6). Dietary fiber content in catfish sausages with seaweed powder was higher than commercial fish sausage, which can be beneficial for human digestion

Table 5. Physical properties of different fish sausage

\begin{tabular}{lccc}
\hline \multirow{2}{*}{ Parameter } & \multicolumn{4}{c}{ Sausage type } \\
& Control & With $0.50 \%$ E.cottonii & Commercial \\
\hline Gel strength (g.cm) & $1,607.48^{a}$ & $1,773.85^{\mathrm{b}}$ & $1,814.34^{\mathrm{b}}$ \\
Folding test & $3.80^{\mathrm{a}}$ & $4.60^{\mathrm{b}}$ & $4.40^{\mathrm{b}}$ \\
Degree of whiteness (\%) & $65.30^{\mathrm{c}}$ & $64.25^{\mathrm{b}}$ & $39.30^{\mathrm{a}}$ \\
WHC (\%) & $85.02^{\mathrm{a}}$ & $88.23^{\mathrm{b}}$ & $87.88^{\mathrm{b}}$ \\
\hline
\end{tabular}
was broken into fragments with finger pressure - no cracks on folding into quarters

Table 6. Nutrition content per $100 \mathrm{~g}$ of fish sausage

\begin{tabular}{|c|c|c|}
\hline \multirow{2}{*}{ Content (g) } & \multicolumn{2}{|c|}{ Sausage Type } \\
\hline & With E. cottonii $0.5 \%$ & Commercial \\
\hline Moisture & $62.48 \pm 0.64$ & $61.91 \pm 0.88$ \\
\hline Ash & $1.20 \pm 0.01$ & $2.45 \pm 0.11$ \\
\hline Protein & $12.22 \pm 0.22$ & $9.47 \pm 0.27$ \\
\hline Fat & $0.57 \pm 0.04$ & $0.51 \pm 0.12$ \\
\hline Carbohydrate & $23.54 \pm 0.59$ & $25.65 \pm 0.91$ \\
\hline Dietary fiber & 22.95 & 15.98 \\
\hline Soluble dietary fiber & 1.88 & 1.33 \\
\hline Insoluble dietary fiber & 21.07 & 14.65 \\
\hline
\end{tabular}




\section{CONCLUSION}

E. cottonii powder improved the quality of catfish sausage in terms of gel strength, folding test, degree of whiteness and WHC. Seaweed powder addition did not change the flavor and color of catfish sausage and gave no bitter properties to it. Concentration of $0.50 \%$ of each seaweed powder gave comparable gel properties with commercial fish sausage and gave more dietary fiber content which can be beneficial.

\section{REFERENCES}

Amiza MA, Ain KN. 2012. Effect of Washing Cycle and Salt Addition on the Properties of Gel Catfish (Pangasius sp.) Surimi. International Annual Symposium of Sustainability Science and Management 11: 485-491.

AOAC. 2005. Official Method of Analysis. Maryland: Association of Official Analytical Chemist.

Cardoso C, Mendes R, Nunes ML. 2008. Development of Healthy Low-Fat Fish Sausage Containing Dietary Fiber. International Journal of Food Science and Technology 43: 276283.

Chaijan M, Panpipat W, Benjakul S. 2010. Physicochemical Properties and Gel Forming Ability of Surimi from Three Species of Mackerel Caught in Southern Thailand. Food Chemistry 121: 85-92.

Gunenc A. 2007 "Evaluation of Pork Meat Quality by Using Water Holding Capacity and VisSpectroscopy" in Yakhin LA, Zhang J, Wang YL, Li ZJ. 201 2. Microstructure, Chemical and Physical Changes of Vacuum-Packed Grass Carp (Ctenopharyngodon idella) Fillets Stored in Low Temperature. Journal of Hunan Agriculture University (Natural Science) 38 (2): 221 224.

Li YT, Jiang YM. 2004. Carrageenan and Cooked Meat Products. Journal Meat 9: 46-47.

Nippon Suisan Kaisha Ltd. 1980. Standard procedure for quality evaluation of frozen surimi. Tokyo, Japan.

Prakashan N. 2008. Pharmacognosy. Abhyudaya Prgati: Nirali Prakashan.

Pietrasik Z, Chan ECY. 2002. Binding and Textural Properties of Beef Gels as Affected by Protein K-carrageenan and Microbial Transglutaminase Addition. Food Research International 35: 91-98.

Ramirez JA, Uresti RM, Velazquez G, Vazquez M. 2011. Food Hydrocolloids as additives to improve the mechanical and functional properties of fis products: A review. Food Hydrocolloids 25: 1842-1852.

Santoso JA, AWN, Santoso. 2008. Perubahan Karakteristik Surimi Ikan Cucut dan Ikan Pari Akibat Pengaruh Pengkomposisiaan dan Penyimpanan Dingin Daging Lumat. Jurnal Teknologi dan Industri Pangan 19(1): 8-17.

Sen DP. 2005. Advances in Fish Processing Technology. New Delhi: Allied Publishers PVT Ltd..

Soriano EM. 2001. Agar Polysacharides from Gracilaria species (Rhodophyta, Gracilariaceae). Journal of Biotechnology 89: 81-84.

Sudarmadji SB, Haryono, Suhardi. 1996. Analisa Bahan Makanan dan Pertanian. Yogyakarta: UGM Press.

Sun XD, Holley RA. 2010. Factors Influencing Gel Formation by Myofibrillar Proteins in Muscle Foods. Comprehensive Reviews in Food Science and Food Safety 10 (1): 33-51.

Syamsuar. 2006. Karakteristik karagenan rumput laut Eucheuma cottonii pada berbagai umur panen, konsentrasi KOH dan lama ekstraksi. [thesis]. Bogor Progam Pascasarjana, IPB.

Yada RY. 2004. Protein in Food Processing. Cambridge: Woodhead Publishing Limited.

Yakhin LA, Santoso J, Tirtajaya I. 2008. Pengaruh penambahan kappa-karagenan terhadap karakteristik bakso ikan nila hitam (Oreochromis niloticus) dan bakso ikan lele dumbo (Clarias gariepinus). Jurnal Ilmu dan Teknologi Pangan Vol. 6 (1). 